\title{
Role of high mobility group A1 and body mass index in the prognosis of patients with breast cancer
}

\author{
SHIZHEN ZHANG ${ }^{1,2^{*}}$, RUI LEI $^{3 *}$, JINGJING WU $^{4 *}$, JINLAN SHAN $^{1,2}$, ZUJIAN HU $^{5}$, \\ LIRONG CHEN ${ }^{2,4}$, XINGCHANG REN $^{6}$, LIFANG YAO $^{4}$, JIAN WANG ${ }^{1,2}$ and XIAOCHEN WANG ${ }^{1,2}$
}

\begin{abstract}
Departments of ${ }^{1}$ Surgical Oncology and ${ }^{2}$ Cancer Institute, Second Affiliated Hospital, Zhejiang University School of Medicine, Hangzhou, Zhejiang 310009; ${ }^{3}$ Department of Plastic Surgery, First Affiliated Hospital, Zhejiang University School of Medicine, Hangzhou, Zhejiang 310003; ${ }^{4}$ Department of Pathology, Second Affiliated Hospital, Zhejiang University School of Medicine, Hangzhou, Zhejiang 310009; Departments of ${ }^{5}$ Breast Surgery and ${ }^{6}$ Pathology, Hangzhou Traditional Chinese Medical Hospital, Hangzhou, Zhejiang 310000, P.R. China
\end{abstract}

Received February 5, 2016; Accepted March 9, 2017

DOI: $10.3892 / \mathrm{ol} .2017 .6963$

\begin{abstract}
The high mobility group A1 (HMGA1) protein is associated with poor prognosis in patients with a wide range of cancers. However, the affect of HMGA1 on the risk of mortality from breast cancer (BC) has not been fully characterized. In the present retrospective multiple center study, the HMGA1 expression level was determined by performing immunohistochemistry on surgical tissue samples of $273 \mathrm{BC}$ specimens from the Second Affiliated Hospital of Zhejiang University (Zhejiang, China) and 310 BCs from the National Engineering Center for Biochip (Shanghai, China). Kaplan-Meier analysis and Cox proportional hazard model were employed to analyze the survivability. HMGA1 expression was significantly associated with tumor histological degree and body mass index (BMI). However, HMGA1 expression showed no prognostic value in patients with BC. Combined evaluation of HMGA1 expression and high BMI $\left(\geq 24 \mathrm{~kg} / \mathrm{m}^{2}\right)$ predicted worse overall survival of BC. Therefore, HMGA1 and BMI were considered to serve synergistic roles in the development and progression of $\mathrm{BC}$, and combined evaluation of HMGA1 expression and high BMI may be an effective marker in predicting poor prognosis of $\mathrm{BC}$ patients.
\end{abstract}

Correspondence to: Professor Xiaochen Wang or Professor Jian Wang, Department of Surgical Oncology, Second Affiliated Hospital, Zhejiang University School of Medicine, 88 Jiefang Road, Hangzhou, Zhejiang 310009, P.R. China

E-mail: wangxiaochen@zju.edu.cn

E-mail: wangjian519@zju.edu.cn

*Contributed equally

Key words: high mobility group A1, breast cancer, body mass index, prognosis, biomarker

\section{Introduction}

Breast cancer (BC) represents the leading cause of cancer-associated mortality in females worldwide (1). As a heterogeneous disease, a series of genetic markers have been evaluated and associated with clinical prognostic parameters in patients with BC (2-4). However, these markers are not yet effective enough to be used in clinical practice, and additional studies are required to produce effective targets that can be used to predict prognosis and drug resistance (5).

The high mobility group A1 (HMGA1) proteins are architectural non-histone chromatin factors, which form stereospecific multiprotein complexes termed enhanceosomes on the promoter/enhancer regions of genes that regulate gene transcription. Each HMGA1 protein has three AT-hook domains that bind to the minor groove of AT-rich DNA sequences and interact with various transcription factors to enhance or inhibit gene transcription $(6,7)$. HMGA1 is involved in a variety of cellular processes, including embryogenesis, cell cycle regulation, senescence, differentiation and DNA repair (8-11). HMGA1 protein overexpression is a feature of malignant tumors, including pancreas, breast and colorectal cancers (12-18). A previous in vitro study provided evidence that HMGA1 exerts an important role in the pathogenesis of breast cancer; exogenous expression of HMGA1 in normal human breast cells may lead to malignant phenotype transformation (19). HMGA1 promoted metastatic processes in breast cancer cells through enhancing cell proliferation, the Hippo signaling pathway and epithelial-to-mesenchymal transition (20-25). In addition, HMGA1 expression in breast cancer cells diminished cellular DNA repair activity by inducing enhanced apoptosis and sensitizing cells to cisplatin-induced death (26). Knockdown of HMGA1 expression altered breast cancer cells to a more differentiated phenotype and reduced breast tumorigenesis $(21,27)$.

A high body mass index (BMI) is an independent risk factor for cardiovascular disease $(28,29)$ and cancer $(30,31)$. Several studies have demonstrated that BMI influences the outcomes of patients with $\mathrm{BC}$ and is considered a prognosis factor (32-35). Furthermore, HMGA protein expression in tumors may also be associated with BMI (36). 
To elucidate the role of HMGA1 and BMI in the prognosis of BC, HMGA1 protein expression was evaluated by immunohistochemical staining in two large cohorts of BC samples. It was identified that HMGA1 expression indicated an advanced BC malignancy, while its expression did not show significant prognostic value. However, the combined evaluation of HMGA1 expression and high BMI may serve as a biomarker of poor prognosis in patients with $\mathrm{BC}$.

\section{Materials and methods}

Patients. The eligible BCs were collected based on inclusion and exclusion criteria. Inclusion criteria: BCs with pathological diagnosis; informed consent obtained or waiver of consent; and follow-up information available. Exclusion criteria: Failed to get informed consent; multiple cancers; lack of histological diagnosis; and no follow-up information. A total of $273 \mathrm{BCs}$ who received surgical operation in the Second Affiliated Hospital of Zhejiang University (Zhejiang, China) were entered as the training set. The validation set, which consisted of 310 patients with $\mathrm{BC}$ who received surgical operation were collected from the National Engineering Center for Biochip (Shanghai, China). In the training set, all patients who received surgical operation between January 2004 and September 2010 were followed up until August 2015. The 310 BCs in the validation set received operations between January 2001 and December 2008, and the last follow-up time was July 2014.

Construction of tissue microarray (TMA). Formalin-fixed and paraffin-embedded tumor specimens were prepared for TMA using the Beecher Manual Tissue Arrayer (Beecher Instruments, Inc., Sun Prairie, WI, USA). Briefly, one core tissue biopsy with a diameter of $1 \mathrm{~mm}$ was taken from a representative region of an individual paraffin-embedded BC sample and placed into a new recipient paraffin block. Every sample included 2-3 tissue cores for biomarker analysis. Consecutive sections of 4-5 mm were cut from TMA blocks and placed on glass slides for subsequent immunohistochemical analysis. The tumor blocks also contained tumor and normal breast tissue samples as positive and negative controls for each IHC staining.

HMGA1 immunohistochemistry. Paraffin sections of 5-6 $\mu \mathrm{m}$ were deparaffinized and antigen was retrieved by boiling for $15 \mathrm{~min}$ in $0.1 \mathrm{M}$ citrate buffer. The endogenous peroxidase activity was blocked with $3 \%$ hydrogen peroxide for $15 \mathrm{~min}$. Array slides were then incubated with normal goat serum (catalog no. ZLI-9021; ZSGB-Bio, Beijing China). for $15 \mathrm{~min}$. The primary antibody HMGA1 (catalog no. ab129153; dilution, 1:250; Abcam, Cambridge, UK) was incubated overnight at $4^{\circ} \mathrm{C}$ in a humidified chamber. The rabbit antibody against HMGA1 (catalog. no. A380388; dilution, 1:5,000) used in the present study was purchased from ALEXIS Biochemicals (San Diego, CA, USA). PBS was used as a negative control. The array slides were incubated with horseradish peroxidase-labeled polymer conjugated with corresponding antibodies for $30 \mathrm{~min}$. Diaminobenzidine (catalog no. D8230; Solarbio, Beijing, China) was then applied for 5 and $10 \mathrm{~min}$, respectively. Each slide was counterstained with hematoxylin (Dako; Agilent Technologies, Inc., Santa Clara, CA, USA).
Scoring of HMGAl expression.HMGA1 staining was assessed for the percentage of nuclear immunoreactivity in tumor cells by two independent observations. Results were grouped into the following categories: No nuclear staining (-); with nuclear staining $<20 \%(+) ; 20-50 \%$ of nuclear positive cells (++); and $>50 \%$ of nuclear positive cells (+++). All clinicopathological data (pathological diagnosis, grade and tumor node metastasis stage) and immunohistochemical data [estrogen receptor (ER), progesterone receptor (PR) and human epidermal growth factor 2 (HER2)] were reevaluated by pathologists from the Department of Pathology (Second Affiliated Hospital, Zhejiang University School of Medicine, Zhejiang, China). BMI scores were divided by 24 according to the Chinese standard which determines that $>24 \mathrm{~kg} / \mathrm{m}^{2}$ is categorized as overweight or obese (37).

Statistical analysis. SPSS 21.0 software (IBM SPSS, Armonk, NY, USA) was used for statistical analysis. The association between HMGA1 expression/BMI and clinicopathological factors was estimated using the Pearson's $\chi^{2}$ test. Overall survival (OS) curves were constructed using the Kaplan-Meier method by the log-rank test. Univariate analysis was performed with the log-rank test, and Cox's regression test was applied for multivariable analysis. The factors of ER status, PR status, HER2 status, tumor size and lymph node involvement were excluded when performed multivariable analysis, as these factors have the collinear relation with TNBC and TNM stage. Hazard ratios (HRs) were reported with $95 \%$ confidence intervals (CIs). $\mathrm{P}<0.05$ was considered to indicate a statistically significant difference.

\section{Results}

HMGA1 expression and clinicopathological characteristics in $B C$. Associations between HMGA1 expression and clinicopathological characteristics of $\mathrm{BC}$ patients are shown in Table I. HMGA1 expression was observed in 105/273 (38.5\%) patients with BC in the training set and 191/310 (61.6\%) in the validation set. HMGA1 staining was negative in all the normal samples (Fig. 1A). The association between positive HMGA1 expression and clinicopathological parameters was then analyzed. It was identified that HMGA1 overexpression was significantly associated with histological grade in the training set $(\mathrm{P}=0.031)$ and the validation set $(\mathrm{P}<0.001)$. However, no significant difference in HMGA1 expression, according to age, tumor location, stage of disease, triple-negative BC (TNBC) or other parameters, was observed (Table I).

BMI and clinicopathological parameters. A total of $158 / 273$ patients with $\mathrm{BC}$ in the training set were recorded with BMI, the association between BMI and associated clinicopathological parameters was analyzed. BMI did not show any association with age, location, tumor stage or other parameters (Table II), however, high BMI $\left(>24 \mathrm{~kg} / \mathrm{m}^{2}\right)$ was significantly associated with HMGA1 expression $(\mathrm{P}=0.033)$.

Survival analysis. In order to clarify whether HMGA1 affects the prognosis of patients with BC, Kaplan-Meier analysis was performed, and it was revealed that HMGA1 level did not predict survival significance in patients with BC. As shown 
Table I. HMGA1 protein expression and clinicopathological characteristics in breast cancer.

\begin{tabular}{|c|c|c|c|c|c|c|}
\hline \multirow[b]{2}{*}{ Characteristics } & \multicolumn{2}{|c|}{ Training set (ZJU, n=273) } & \multirow[b]{2}{*}{ P-value } & \multicolumn{2}{|c|}{ Validation set (SBC, $\mathrm{n}=310$ ) } & \multirow[b]{2}{*}{ P-value } \\
\hline & Patients, $\mathrm{n}$ & $\mathrm{HMGA}^{+}, \mathrm{n}(\%)$ & & Patients, $\mathrm{n}$ & $\mathrm{HMGA}^{+}, \mathrm{n}(\%)$ & \\
\hline Age & & & 0.863 & & & 0.983 \\
\hline$\leq 50$ years & 136 & $53(39.0)$ & & 117 & $72(61.5)$ & \\
\hline$>50$ years & 137 & $52(38.0)$ & & 193 & $119(61.7)$ & \\
\hline Tumor location ${ }^{\mathrm{a}}$ & & & 0.377 & & & 0.604 \\
\hline Left & 147 & $53(36.1)$ & & 136 & $86(63.2)$ & \\
\hline Right bilateral & 126 & $52(41.3)$ & & 174 & $105(60.3)$ & \\
\hline Histological grade ${ }^{\mathrm{b}}$ & & & 0.031 & & & $<0.001$ \\
\hline I & 45 & $13(28.9)$ & & 51 & $18(35.3)$ & \\
\hline II & 119 & $45(37.8)$ & & 195 & $121(62.1)$ & \\
\hline III & 24 & $14(58.3)$ & & 64 & $52(81.3)$ & \\
\hline Tumor size & & & 0.188 & & & 0.614 \\
\hline $\mathrm{T} 1$ & 125 & $45(36.0)$ & & 78 & $41(52.6)$ & \\
\hline $\mathrm{T} 2$ & 129 & $50(38.8)$ & & 199 & $131(65.8)$ & \\
\hline $\mathrm{T} 3$ and $\mathrm{T} 4$ & 19 & $10(52.6)$ & & 33 & 19 (57.6) & \\
\hline Lymph node involvement & & & 0.631 & & & 0.073 \\
\hline$N(-)$ & 148 & $55(37.2)$ & & 145 & $97(66.9)$ & \\
\hline $\mathrm{N}(+)$ & 125 & $50(40.0)$ & & 165 & $94(57.0)$ & \\
\hline AJCC stage & & & 0.133 & & & 0.664 \\
\hline I & 82 & $26(31.7)$ & & 41 & $24(58.5)$ & \\
\hline II & 128 & $52(40.6)$ & & 181 & $117(64.6)$ & \\
\hline III & 63 & $27(42.9)$ & & 88 & $50(56.8)$ & \\
\hline ER status & & & 0.798 & & & 0.192 \\
\hline Negative & 104 & $39(37.5)$ & & 113 & $75(66.4)$ & \\
\hline Positive & 169 & $66(39.1)$ & & 197 & $116(58.9)$ & \\
\hline PR status & & & 0.510 & & & 0.501 \\
\hline Negative & 116 & $42(36.2)$ & & 156 & $99(63.5)$ & \\
\hline Positive & 157 & $63(40.1)$ & & 154 & $92(59.7)$ & \\
\hline HER2 status & & & 0.609 & & & 0.075 \\
\hline Negative & 214 & $84(39.3)$ & & 208 & $121(58.2)$ & \\
\hline Positive & 59 & $21(35.6)$ & & 102 & 70 (67.6) & \\
\hline Triple-negative & & & 0.740 & & & 0.442 \\
\hline TNBC & 68 & $25(36.8)$ & & 46 & $26(56.5)$ & \\
\hline Others & 205 & $80(39.0)$ & & 264 & $165(62.5)$ & \\
\hline
\end{tabular}

an the validation set there are three bilateral breast cancers. ${ }^{\mathrm{b}}$ In the training set there were 85 cases without data. Student's $t$ test was used for comparisons between 2 groups of experiments, and one-way ANOVA analysis was used for comparisons among 3 or more groups. $\mathrm{P}<0.05$ was considered significant. ZJU, Zhejiang university; SBC, Shanghai Biochip Center; ER, estrogen receptor; PR, progesterone receptor; HER2, human epidermal growth factor 2; TNBC, triple-negative breast cancer; AJCC, American joint committee on cancer.

in Fig. 2A and B, HMGA1 did not affect the OS of patients with $\mathrm{BC}$ in the training set $(\mathrm{P}=0.382)$ or the validation set $(\mathrm{P}=0.570)$. The results of Cox's regression test are presented in Table III. As expected, the univariate analysis revealed that tumor stages 3 and 4, lymph node involvement, American Joint Committee on Cancer (AJCC) stages II and III, histological grade III and TNBC subtype were associated with unfavorable prognosis; while ER (+) and PR (+) were associated with favorable prognosis in the training cohort. These results were confirmed in the validation cohort. Multivariate analysis indicated that the AJCC stage in the training set (HR, 5.01; CI, 2.19-11.47) and the validation set (HR, 2.02; CI, 1.20-2.89), and TNBC status in the training set (HR, 4.35; CI, 1.61-11.75) and the validation set (HR, 2.77; CI, 1.69-4.56) were the independent prognostic risk of patients with BC. HMGA1 expression was not associated with OS in the training set (HR, 0.79; CI, 0.29-2.14; Fig. 2C) or in the validation set (HR, 0.78; CI, 0.49-1.23; Fig. 2D).

The association between BMI and prognosis in the group of 158 patients with BC was then analyzed, and it was identified 

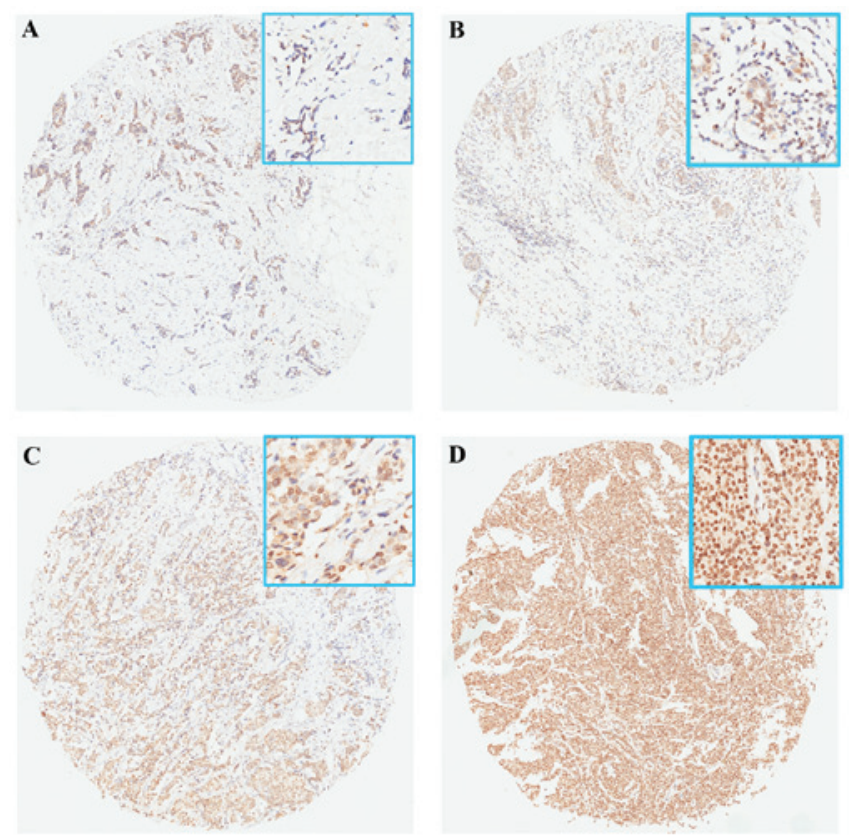

Figure 1. Immunohistochemical analysis of HMGA1 in breast cancer tissues with (A) negative, (B) weakly positive, (C) moderately positive and (D) strongly positive staining. Each slide was investigated in with low magnification (40x) and then with high magnification (200x) under a microscope (Olympus, Tokyo, Japan).

that high BMI was associated with poor OS ( $\mathrm{P}=0.024$; Fig. $3 \mathrm{~A})$, but not associated with disease-free survival (DFS; $\mathrm{P}=0.733$; Fig. 3B). In addition, BMI and HMGA1 combined (HMGA1 positive and $\left.\mathrm{BMI}>24 \mathrm{~kg} / \mathrm{m}^{2}\right)$ evaluation had a stronger association with OS ( $\mathrm{P}=0.004$; Fig. $3 \mathrm{C})$ and DFS $(\mathrm{P}=0.074$; Fig. 3D). Cox's regression test was then performed (Table IV). BMI (HR, 2.23; CI, 1.09-4.56) and BMI/HMGA2 combined score (HR, 2.83; CI, 1.25-5.95) had a significant adverse prognosis value for OS (HR, 1.32; CI, 0.70-2.50), but not with DFS (HR, 1.86; CI, 0.93-3.73) in univariate analysis. However, the prognostic value of the combined BMI and HMGA1 score was dampened in multivariate analysis; the HRs of the high BMI-HMGA1 combined score with DFS and OS were 1.82 (CI, 0.58-5.62) and 4.21 (CI, 0.61-29.00), respectively.

\section{Discussion}

In the present study, HMGA1 expression in 583 patients with $\mathrm{BC}$ was retrospectively analyzed from two medical centers, to clarify the expression patterns of HMGA1 in BC samples. In total, $38.5 \%$ of patients with $\mathrm{BC}$ in the training set and $61.6 \%$ of patients in the validation set showed HMGA1 expression. The discrepancy of HMGA1 expression ratio may be due to the difference of baseline characteristics of patients from these two sets. In the training set, $93.0 \%$ of patients were stage I and II, and $24.9 \%$ of patients had TNBC, while in the validation set, $83.2 \%$ of patients were identified as stage I and II, and only $14.8 \%$ of patients were classified as TNBC. The oncogenic protein HMGA1 has been established as the prognostic and predictive marker of survival in various types of cancers $(16,38,39)$. Its expression preceded the appearance of the malignant phenotype, as only $40 \%$ of hyperplastic lesions with cellular atypia were stained for HMGA1, while
Table II. Association between body mass index and clinicopathological characteristics of patients with breast cancer.

\begin{tabular}{|c|c|c|c|}
\hline \multirow[b]{2}{*}{ Characteristic } & \multicolumn{3}{|c|}{$\mathrm{BMI}, \mathrm{kg} / \mathrm{m}^{2}$} \\
\hline & $<24$ & $\geq 24$ & P-value \\
\hline Age (years) & & & 0.249 \\
\hline$\leq 50$ & 51 & 22 & \\
\hline$>50$ & 57 & 28 & \\
\hline Tumor location ${ }^{\mathrm{a}}$ & & & 0.249 \\
\hline Left & 52 & 29 & \\
\hline Right bilateral & 56 & 21 & \\
\hline Histological grade ${ }^{b}$ & & & 0.080 \\
\hline I & 25 & 8 & \\
\hline II & 53 & 18 & \\
\hline III & 8 & 7 & \\
\hline Tumor size & & & 0.437 \\
\hline $\mathrm{T} 1$ & 53 & 25 & \\
\hline $\mathrm{T} 2$ & 48 & 20 & \\
\hline T3 and T4 & 7 & 5 & \\
\hline Lymph node involvement & & & 0.455 \\
\hline $\mathrm{N}(-)$ & 63 & 26 & \\
\hline $\mathrm{N}(+)$ & 45 & 24 & \\
\hline AJCC stage & & & 0.851 \\
\hline I & 34 & 15 & \\
\hline II & 55 & 21 & \\
\hline III & 19 & 14 & \\
\hline ER status & & & 0.410 \\
\hline Negative & 38 & 21 & \\
\hline Positive & 70 & 29 & \\
\hline PR status & & & 0.384 \\
\hline Negative & 46 & 25 & \\
\hline Positive & 62 & 25 & \\
\hline HER2 status & & & 0.169 \\
\hline Negative & 97 & 41 & \\
\hline Positive & 11 & 9 & \\
\hline Triple-negative & & & 0.893 \\
\hline TNBC & 81 & 37 & \\
\hline Others & 27 & 13 & \\
\hline HMGA1 status & & & 0.033 \\
\hline Negative & 65 & 21 & \\
\hline Positive & 43 & 29 & \\
\hline
\end{tabular}

${ }^{\mathrm{a}}$ In the validation set there are 3 bilateral breast cancers. ${ }^{\mathrm{b}}$ In the training set there were 85 cases without data. Student's t-test was used for comparisons between 2 groups of experiments, and one-way ANOVA analysis was used for comparisons among 3 or more groups. $\mathrm{P}<0.05$ was considered significant. BMI, body mass index; ER, estrogen receptor; PR, progesterone receptor; HER2, human epidermal growth factor 2; TNBC, triple-negative breast cancer; AJCC, American joint committee on cancer; HMGA1, high mobility group A1.

$62 \%$ of breast carcinomas were HMGA1 expression (12). In the present study, HMGA1 expression determined by 

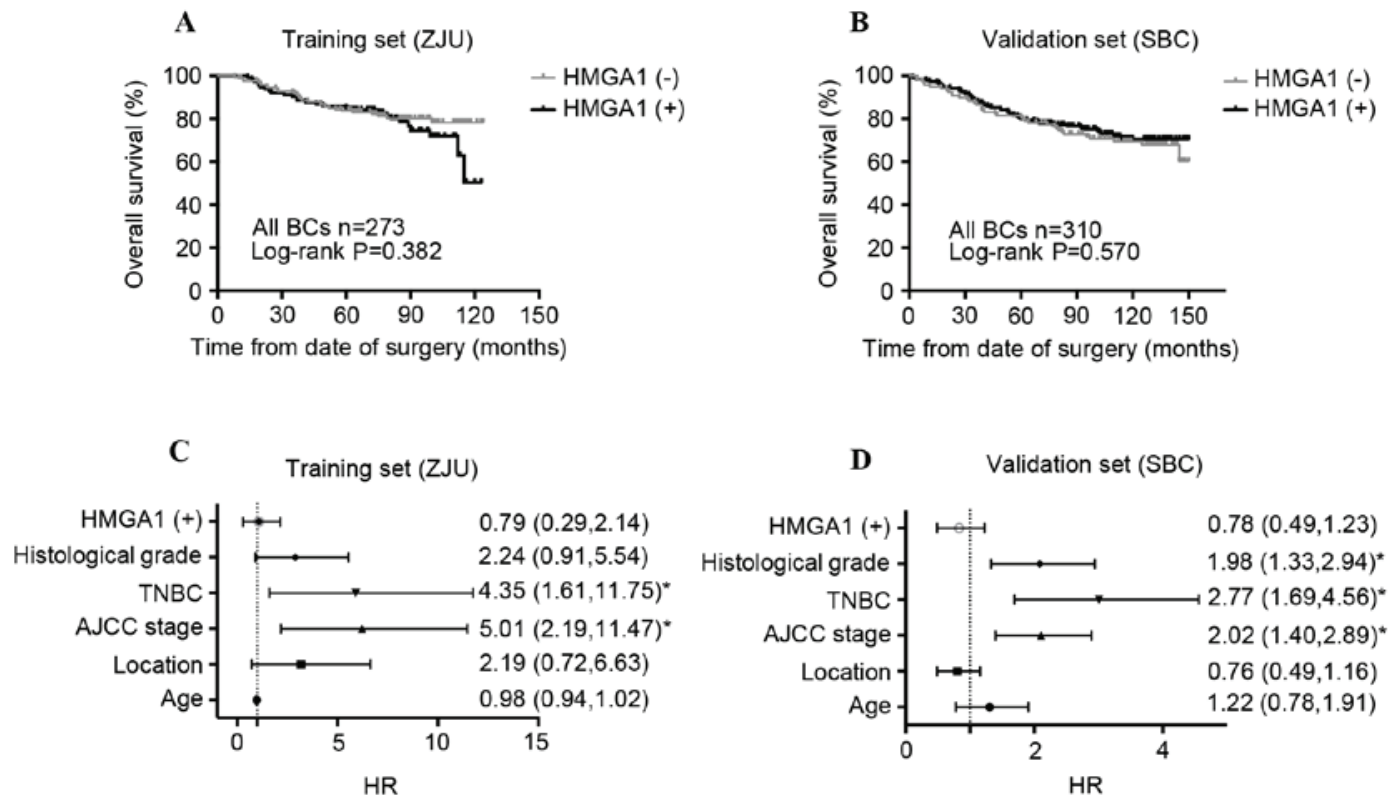

Figure 2. Prognostic significance of HMGA1 expression in breast cancer. (A) Kaplan-Meier OS analysis of HMGA1 expression for all patients in the training and (B) validation cohort. (C) Forest plots of the results of multivariate Cox analysis for OS in the training and (D) validation cohort. OS, overall survival; HMGA1, high mobility grade A1; ZJU, Zhejiang university; SBC, Shanghai biochip center; TNBC, triple-negative breast cancer; HR, hazard ratio. ${ }^{*} \mathrm{P}<0.05$.

Table III. Univariate and multivariate Cox analysis for high mobility group A1 and survival of breast cancer.

\begin{tabular}{|c|c|c|c|c|}
\hline \multirow[b]{2}{*}{ Characteristic } & \multicolumn{2}{|c|}{ Training set (ZJU, n=273) } & \multicolumn{2}{|c|}{ Validation set (SBC, $\mathrm{n}=310)$} \\
\hline & $\begin{array}{c}\text { Univariate, } \\
\text { HR }(95 \% \text { CI) }\end{array}$ & $\begin{array}{l}\text { Multivariate, } \\
\text { HR }(95 \% \text { CI })\end{array}$ & $\begin{array}{c}\text { Univariate, } \\
\text { HR }(95 \% \text { CI })\end{array}$ & $\begin{array}{l}\text { Multivariate, } \\
\text { HR }(95 \% \text { CI })\end{array}$ \\
\hline Age ( $>50$ vs. $\leq 50$ years $)$ & $1.02(0.99-1.04)$ & $0.98(0.94-1.02)$ & $1.10(0.71-1.70)$ & $1.22(0.78-1.91)$ \\
\hline Location (right vs. left) & $1.19(0.69-2.03)$ & $2.19(0.72-6.63)$ & $0.86(0.57-1.29)$ & $0.76(0.49-1.16)$ \\
\hline ER status (+ vs. -) & $0.33(0.19-0.58)^{\mathrm{a}}$ & & $0.60(0.39-0.91)^{\mathrm{a}}$ & \\
\hline PR status (+ vs. -) & $0.28(0.16-0.50)^{\mathrm{a}}$ & & $0.54(0.35-0.83)^{\mathrm{a}}$ & \\
\hline HER2 status (+ vs. -) & $1.53(0.84-2.79)$ & & $1.50(0.98-2.31)$ & \\
\hline Tumor size (T3/4 vs. T1/2) & $2.01(1.35-2.99)^{\mathrm{a}}$ & & $1.73(1.23-2.44)^{\mathrm{a}}$ & \\
\hline Lymph node involvement (+ vs. -) & $1.98(1.58-2.48)^{\mathrm{a}}$ & & $1.46(1.19-1.80)^{\mathrm{a}}$ & \\
\hline AJCC stage (II/III vs. I) & $3.62(2.35-5.58)^{\mathrm{a}}$ & $5.01(2.19-11.47)^{\mathrm{a}}$ & $2.10(1.47-2.99)^{\mathrm{a}}$ & $2.02(1.40-2.89)^{\mathrm{a}}$ \\
\hline TNBC (TNBC vs. non-TNBC) & $3.32(1.94-5.70)^{\mathrm{a}}$ & $4.35(1.61-11.75)^{\mathrm{a}}$ & $2.45(1.52-3.94)^{\mathrm{a}}$ & $2.77(1.69-4.56)^{\mathrm{a}}$ \\
\hline Histological grade (III vs. I/II) & $3.65(1.61-8.31)^{\mathrm{a}}$ & $2.24(0.91-5.54)$ & $1.70(1.19-2.42)^{\mathrm{a}}$ & $1.98(1.33-2.94)^{\mathrm{a}}$ \\
\hline HMGA1 (+ vs. -) & $1.05(0.61-1.82)$ & $0.79(0.29-2.14)$ & $0.88(0.58-1.35)$ & $0.78(0.49-1.23)$ \\
\hline
\end{tabular}

${ }^{a} \mathrm{P}<0.05$. HR, hazard ratio; CI, confidence interval; ER, estrogen receptor; PR, progesterone receptor; HER2, human epidermal growth factor 2; TNBC, triple-negative breast cancer; AJCC, American joint committee on cancer; HMAG1, high mobility grade A1.

immunohistochemistry did not show any association with OS in patients with $\mathrm{BC}$, while HMGA1 expression was significantly associated with histological grade of patients with $\mathrm{BC}$, which is consistent with previous studies $(12,40,41)$.

$\mathrm{BMI}$ is a simple measurement based on individual weight and height, it is widely used to define overweight and obesity. High BMI has been identified as a major risk of type 2 diabetes mellitus (T2DM) (42). The presence of a functional variant of the HMGA1 gene was also associated with T2DM (43), and this HMGA1 variant positively associated with BMI (44). From these results, it was inferred that an association may exist between HMGA1 and BMI. Notably, HMGA1 expression was found to be significantly associated with BMI in patients with $\mathrm{BC} ; 62.5 \%$ of HMGA1 positive patients were overweight or obese $\left(\mathrm{BMI} \geq 24 \mathrm{~kg} / \mathrm{m}^{2}\right.$ ), while only $17.8 \%$ of HMGA1 negative patients were overweight. Survival analysis resulted in poor OS for BC patients with high BMI $\left(\geq 24 \mathrm{~kg} / \mathrm{m}^{2}\right)$. Although HMGA1 expression did not indicate any prognostic value in patients with $\mathrm{BC}$, the HMGA1 expression and BMI combined score had a stronger prognostic value for OS (Fig. 3B, P=0.004). Similarly, BMI did not have prognostic value for DFS $(\mathrm{P}=0.733)$, but the HMGA1 expression and BMI combined score showed a trend in association with DFS $(\mathrm{P}=0.074)$. It was hypothesized that HMGA1 and BMI may 
A

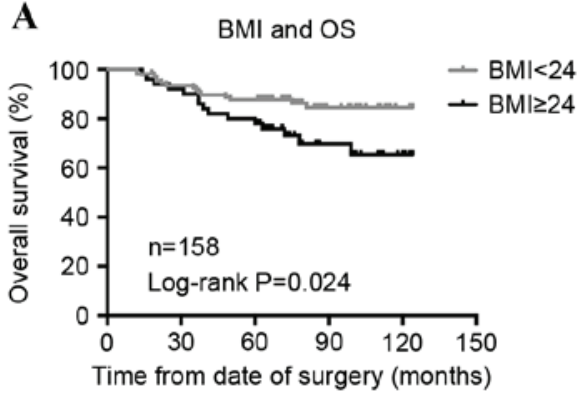

C

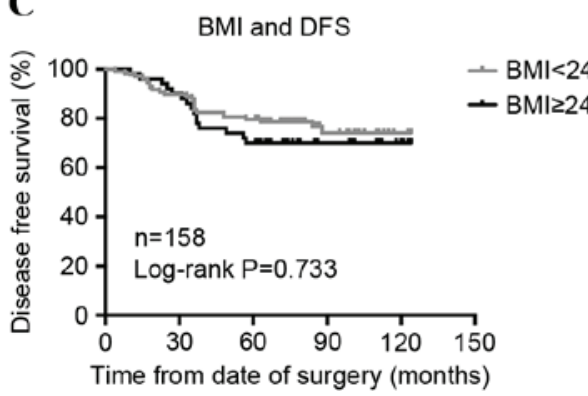

B BMI combined with HMGA1 and OS

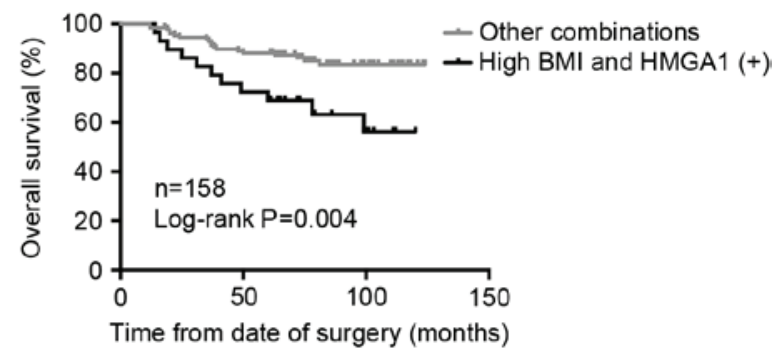

D BMI combined with HMGA1 and DFS

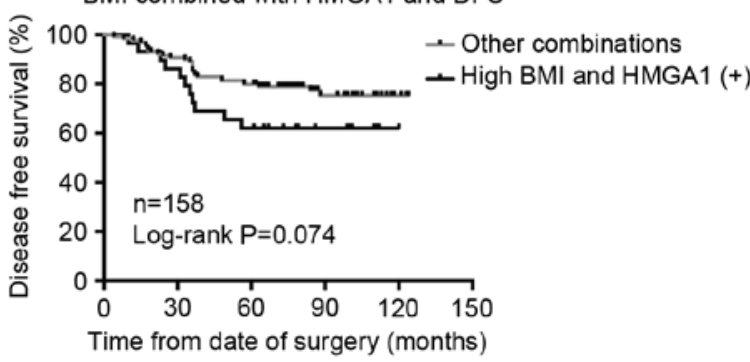

Figure 3. (A) is showing BMI and OS by Kaplan-Meier analysis. (B) is showing BMI and DFS by Kaplan-Meier analysis. (C) is showing HMGA1 and BMI combine score and OS by Kaplan-Meier analysis. (D) is showing HMGA1 and BMI combine score and DFS by Kaplan-Meier analysis; HMGA1, high mobility grade A1; DFS, disease-free survival; BMI, body mass index.

Table IV. Univariate and multivariate Cox analysis of prognostic factors for disease-free survival and overall survival in 158 patients with breast cancer.

\begin{tabular}{|c|c|c|c|c|}
\hline \multirow[b]{2}{*}{ Factors } & \multicolumn{2}{|c|}{ Disease-free survival } & \multicolumn{2}{|c|}{ Overall survival } \\
\hline & $\begin{array}{l}\text { Univariate, } \\
\text { HR }(95 \% \text { CI })\end{array}$ & $\begin{array}{l}\text { Multivariate, } \\
\text { HR }(95 \% \mathrm{CI})\end{array}$ & $\begin{array}{l}\text { Univariate, } \\
\text { HR }(95 \% \text { CI })\end{array}$ & $\begin{array}{l}\text { Multivariate, } \\
\text { HR }(95 \% \mathrm{CI})\end{array}$ \\
\hline Location (right vs. left) & $1.15(0.62-2.14)$ & & $1.31(0.64-2.70)$ & \\
\hline HMGA1 (+ vs. -) & $1.55(0.83-2.90)$ & & $1.90(0.92-3.95)$ & \\
\hline BMI ( $\geq 24$ vs. <24) & $1.32(0.70-2.50)$ & & $2.23(1.09-4.56)^{\mathrm{a}}$ & \\
\hline Age ( $>50$ vs. $\leq 50$ years) & $1.03(1.01-1.05)^{\mathrm{a}}$ & $1.01(0.98-1.05)$ & $1.03(1.00-1.06)^{\mathrm{a}}$ & $0.96(0.88-1.04)$ \\
\hline AJCC stage (II/III vs. I) & $2.94(1.83-4.71)^{\mathrm{a}}$ & $1.66(0.82-3.37)$ & $4.95(2.69-9.11)^{\mathrm{a}}$ & $2.76(0.68-11.25)$ \\
\hline TNBC (TNBC vs. non-TNBC) & $3.58(1.93-6.67)^{\mathrm{a}}$ & $3.12(1.25-7.83)^{\mathrm{a}}$ & $4.63(2.24-9.55)^{\mathrm{a}}$ & $5.07(0.95-27.12)$ \\
\hline Histological grade (III vs. I/II) & $1.69(0.79-3.61)$ & $1.06(0.47-2.41)$ & $14.63(3.43-62.52)^{\mathrm{a}}$ & $8.70(1.21-62.28)^{\mathrm{a}}$ \\
\hline $\begin{array}{l}\text { BMI-HMGA1 combined score } \\
\text { (high vs. low) }\end{array}$ & $1.86(0.93-3.73)$ & $1.82(0.58-5.64)$ & $2.83(1.35-5.95)^{\mathrm{a}}$ & $4.21(0.61-29.00)$ \\
\hline
\end{tabular}

${ }^{\mathrm{a}} \mathrm{P}<0.05$. BMI, body mass index; TNBC, triple-negative breast cancer; HMGA1, high mobility grade A1; AJCC, American joint committee on cancer.

perform a synergistic role in the process of tumorigenesis. HMGA1 protein directly binds to an adipose-specific promoter CCAAT-enhancer-binding protein- $\beta$ to exert a critical role in adipocyte hemostasis, and suppression of HMGA1 expression impaired adipocytic differentiation and decreased fat tissue development (45). Adipocytes promoted the secretion of peptide hormone cholecystokinin of cancer cells and enhanced the proliferation of prostate cancer stem cells (46). In addition, the leptin, which was produced by adipocytes, was suggested to contribute to tumor development and progression through activating the Janus kinase/signal transducers and activators of transcription, phosphatidylinositol 3-kinase/AKT and extracellular signal-related kinase signaling pathways $(47,48)$. It was hypothesized that HMGA1 may enhance the proliferation of adipocytes, particularly adipocytes around the cancer cells, which may interact with cancer cells by secreting specific cytokines to promote the malignant biological properties of cancer cells. However, additional studies are required to elucidate the particular molecular mechanisms underlying this connection among HMGA1, obesity and BC.

The BC tissues included in the present study were collected from two medical centers; however, complete pathological 
BMI and DFS data could not be obtained for all samples. Therefore, the potential selection bias and confounding bias was inevitable. BMI and HMGA2 combined score had a significant adverse prognosis value for OS in univariate analysis. However, it did not indicate an independent risk in multivariate analysis. A lack of enough samples of patients with BMI, the presence of collinearity between BMI-HMGA1 combined score and other clinicopathological parameters, or other confounding factors, may affect the reliability of the results.

In conclusion, the present study demonstrated that HMGA1 expression in $\mathrm{BC}$ is positively associated with pathological differentiation. However, HMGA1 expression is not prognostic of survival in patients with $\mathrm{BC}$. The combined evaluation of HMGA1 expression and high BMI can be a more effective marker in predicting poor prognosis of patients with BC. HMGA1 and BMI may play a synergistic role in the development and progression of $\mathrm{BC}$.

\section{References}

1. Siegel RL, Miller KD and Jemal A: Cancer statistics, 2015. CA Cancer J Clin 65: 5-29, 2015.

2. Oliveira Rodrigues FF, Dos Santos RE, de Oliveira AL, de Lima Rozenowicz R, de Melo MB and Scheffer DK: Prognostic assessment of polymorphisms of the MDR-1 and GSTP1 genes in patients with stage II and III breast cancer submitted to neoadjuvant chemotherapy. Breast J 18: 185-187, 2012.

3. Horak CE, Pusztai L, Xing G, Trifan OC, Saura C, Tseng LM, Chan S, Welcher R and Liu D: Biomarker analysis of neoadjuvant doxorubicin/cyclophosphamide followed by ixabepilone or paclitaxel in early-stage breast cancer. Clin Cancer Res 19: 1587-1595, 2013.

4. Silva JM, Dominguez G, Silva J, Garcia JM, Sanchez A, Rodriguez O, Provencio M, España P and Bonilla F: Detection of epithelial messenger RNA in the plasma of breast cancer patients is associated with poor prognosis tumor characteristics. Clin Cancer Res 7: 2821-2825, 2001.

5. Cianfrocca M and Gradishar W: New molecular classifications of breast cancer. CA Cancer J Clin 59: 303-313, 2009.

6. Thanos D and Maniatis T: Virus induction of human IFN beta gene expression requires the assembly of an enhanceosome. Cell 83: 1091-1100, 1995.

7. Reeves R and Nissen MS: The A.T-DNA-binding domain of mammalian high mobility group I chromosomal proteins. A novel peptide motif for recognizing DNA structure. J Biol Chem 265: 8573-8582, 1990.

8. Chiappetta G, Avantaggiato V, Visconti R, Fedele M, Battista S, Trapasso F, Merciai BM, Fidanza V, Giancotti V, Santoro M, et al: High level expression of the HMGI (Y) gene during embryonic development. Oncogene 13: 2439-2446, 1996.

9. Pomeroy SL, Tamayo P, Gaasenbeek M, Sturla LM, Angelo M, McLaughlin ME, Kim JY, Goumnerova LC, Black PM, Lau C, et al: Prediction of central nervous system embryonal tumour outcome based on gene expression. Nature 415: 436-442, 2002.

10. Narita M, Narita M, Krizhanovsky V, Nuñez S, Chicas A, Hearn SA, Myers MP and Lowe SW: A novel role for high-mobility group a proteins in cellular senescence and heterochromatin formation. Cell 126: 503-514, 2006.

11. Adair JE, Maloney SC, Dement GA, Wertzler KJ, Smerdon MJ and Reeves R: High-mobility group A1 proteins inhibit expression of nucleotide excision repair factor xeroderma pigmentosum group A. Cancer Res 67: 6044-6052, 2007.

12. Chiappetta G, Botti G, Monaco M, Pasquinelli R, Pentimalli F, Di Bonito M, D'Aiuto G, Fedele M, Iuliano R, Palmieri EA, et al: HMGA1 protein overexpression in human breast carcinomas: Correlation with ErbB2 expression. Clin Cancer Res 10: 7637-7644, 2004.

13. Liau SS, Jazag A and Whang EE: HMGA1 is a determinant of cellular invasiveness and in vivo metastatic potential in pancreatic adenocarcinoma. Cancer Res 66: 11613-11622, 2006.
14. Piscuoglio S, Zlobec I, Pallante P, Sepe R, Esposito F, Zimmermann A, Diamantis I, Terracciano L, Fusco A and Karamitopoulou E: HMGA1 and HMGA2 protein expression correlates with advanced tumour grade and lymph node metastasis in pancreatic adenocarcinoma. Histopathology 60: 397-404, 2012.

15. Fedele M, Fidanza V, Battista S, Pentimalli F, Klein-Szanto AJ, Visone R, De Martino I, Curcio A, Morisco C, Del Vecchio L, et al: Haploinsufficiency of the Hmgal gene causes cardiac hypertrophy and myelo-lymphoproliferative disorders in mice. Cancer Res 66: 2536-2543, 2006.

16. Liau SS, Rocha F, Matros E, Redston M and Whang E: High mobility group AT-hook 1 (HMGA1) is an independent prognostic factor and novel therapeutic target in pancreatic adenocarcinoma. Cancer 113: 302-314, 2008.

17. Liau SS and Whang E: HMGA1 is a molecular determinant of chemoresistance to gemcitabine in pancreatic adenocarcinoma. Clin Cancer Res 14: 1470-1477, 2008.

18. Williams MD, Zhang X, Belton AS, Xian L, Huso T, Park JJ, Siems WF, Gang DR, Resar LM, Reeves R and Hill HH Jr: HMGA1 drives metabolic reprogramming of intestinal epithelium during hyperproliferation, polyposis, and colorectal carcinogenesis. J Proteome Res 14: 1420-1431, 2015.

19. Dolde CE, Mukherjee M, Cho C and Resar LM: HMG-I/Y in human breast cancer cell lines. Breast Cancer Res Treat 71: 181-191, 2002.

20. Pegoraro S, Ros G, Ciani Y, Sgarra R, Piazza S and Manfioletti G: A novel HMGA1-CCNE2-YAP axis regulates breast cancer aggressiveness. Oncotarget 6: 19087-19101, 2015.

21. Pegoraro S, Ros G, Piazza S, Sommaggio R, Ciani Y, Rosato A, Sgarra R, Del Sal G and Manfioletti G: HMGA1 promotes metastatic processes in basal-like breast cancer regulating EMT and stemness. Oncotarget 4: 1293-1308, 2013.

22. Treff NR, Dement GA, Adair JE, Britt RL, Nie R, Shima JE, Taylor WE and Reeves R: Human KIT ligand promoter is positively regulated by HMGA1 in breast and ovarian cancer cells. Oncogene 23: 8557-8562, 2004.

23. Liu WM, Guerra-Vladusic FK, Kurakata S, Lupu R and Kohwi-Shigematsu T: HMG-I(Y) recognizes base-unpairing regions of matrix attachment sequences and its increased expression is directly linked to metastatic breast cancer phenotype Cancer Res 59: 5695-5703, 1999.

24. Reeves R, Edberg DD and Li Y: Architectural transcription factor HMGI(Y) promotes tumor progression and mesenchymal transition of human epithelial cells. Mol Cell Biol 21: 575-594, 2001.

25. Resar LM: The high mobility group A1 gene: Transforming inflammatory signals into cancer? Cancer Res 70: 436-439, 2010.

26. Baldassarre G, Belletti B, Battista S, Nicoloso MS, Pentimalli F, Fedele M, Croce CM and Fusco A: HMGA1 protein expression sensitizes cells to cisplatin-induced cell death. Oncogene 24: 6809-6819, 2005.

27. Di Cello F, Shin J, Harbom K and Brayton C: Knockdown of HMGA1 inhibits human breast cancer cell growth and metastasis in immunodeficient mice. Biochem Biophys Res Commun 434: 70-74, 2013.

28. Manson JE, Colditz GA, Stampfer MJ, Willett WC, Rosner B, Monson RR, Speizer FE and Hennekens CH: A prospective study of obesity and risk of coronary heart disease in women. $\mathrm{N}$ Engl J Med 322: 882-889, 1990.

29. Song YM, Sung J, Davey Smith G and Ebrahim S: Body mass index and ischemic and hemorrhagic stroke: A prospective study in Korean men. Stroke 35: 831-836, 2004

30. Calle EE, Rodriguez C, Walker-Thurmond $\mathrm{K}$ and Thun MJ: Overweight, obesity, and mortality from cancer in a prospectively studied cohort of U.S. adults. N Engl J Med 348: 1625-1638, 2003.

31. Reeves GK, Pirie K, Beral V, Green J, Spencer E and Bull D; Million Women Study Collaboration: Cancer incidence and mortality in relation to body mass index in the Million Women Study: Cohort study. BMJ 335: 1134, 2007.

32. Sparano JA, Wang M, Zhao F, Stearns V, Martino S, Ligibel JA, Perez EA, Saphner T, Wolff AC, Sledge GW Jr, et al: Obesity at diagnosis is associated with inferior outcomes in hormone receptor-positive operable breast cancer. Cancer 118: 5937-5946, 2012.

33. Berclaz G, Li S, Price KN, Coates AS, Castiglione-Gertsch M, Rudenstam CM, Holmberg SB, Lindtner J, Erien D, Collins J, et al: Body mass index as a prognostic feature in operable breast cancer: The international breast cancer study group experience. Ann Oncol 15: 875-884, 2004. 
34. Chan DS, Vieira AR, Aune D, Bandera EV, Greenwood DC, McTiernan A, Navarro Rosenblatt D, Thune I, Vieira R and Norat T: Body mass index and survival in women with breast cancer-systematic literature review and meta-analysis of 82 follow-up studies. Ann Oncol 25: 1901-1914, 2014.

35. Widschwendter P, Friedl TW, Schwentner L, DeGregorio N, Jaeger B, Schramm A, Bekes I, Deniz M, Lato K and Weissenbacher T, et al: The influence of obesity on survival in early, high-risk breast cancer: Results from the randomized SUCCESS A trial. Breast Cancer Res 17: 129, 2015.

36. Califano D, Pignata S, Losito NS, Ottaiano A, Greggi S, De Simone V, Cecere S, Aiello C, Esposito F, Fusco A and Chiappetta G: High HMGA2 expression and high body mass index negatively affect the prognosis of patients with ovarian cancer. J Cell Physiol 229: 53-59, 2014.

37. Adult weight determination. The national health and family planning commission of the People's Republic of China. 2013-04-18.

38. Huang R, Huang D, Dai W and Yang F: Overexpression of HMGA1 correlates with the malignant status and prognosis of breast cancer. Mol Cell Biochem 404: 251-257, 2015.

39. Fedele M and Fusco A: HMGA and cancer. Biochim Biophys Acta 1799: 48-54, 2010.

40. Ram TG, Reeves R and Hosick HL: Elevated high mobility group- $\mathrm{I}(\mathrm{Y})$ gene expression is associated with progressive transformation of mouse mammary epithelial cells. Cancer Res 53: 2655-2660, 1993.

41. Flohr AM, Rogalla P, Bonk U, Puettmann B, Buerger H, Gohla G, Packeisen J, Wosniok W, Loeschke S and Bullerdiek J: High mobility group protein HMGA1 expression in breast cancer reveals a positive correlation with tumour grade. Histol Histopathol 18: 999-1004, 2003.
42. Ganz ML, Wintfeld N, Li Q, Alas V, Langer J and Hammer M: The association of body mass index with the risk of type 2 diabetes: A case-control study nested in an electronic health records system in the United States. Diabetol Metab Syndr 6: 50, 2014.

43. Chiefari E, Tanyolac S, Paonessa F, Pullinger CR, Capula C, Iiritano S, Mazza T, Forlin M, Fusco A, Durlach V, et al: Functional variants of the HMGA1 gene and type 2 diabetes mellitus. JAMA 305: 903-912, 2011.

44. Chiefari E, Tanyolaç S, Iiritano S, Sciacqua A, Capula C, Arcidiacono B, Nocera A, Possidente K, Baudi F, Ventura V, et al: A polymorphism of HMGA1 is associated with increased risk of metabolic syndrome and related components. Sci Rep 3: 1491, 2013.

45. Melillo RM,Pierantoni GM,Scala S,Battista S,Fedele M, Stella A, De Biasio MC, Chiappetta G, Fidanza V, Condorelli G, et al: Critical role of the HMGI(Y) proteins in adipocytic cell growth and differentiation. Mol Cell Biol 21: 2485-2495, 2001.

46. Tang KD, Liu J, Jovanovic L, An J, Hill MM, Vela I, Lee TK, Ma S, Nelson C, Russell PJ, et al: Adipocytes promote prostate cancer stem cell self-renewal through amplification of the cholecystokinin autocrine loop. Oncotarget 7: 4939-4948, 2016.

47. Uddin S, Bu R, Ahmed M, Abubaker J, Al-Dayel F, Bavi P and Al-Kuraya KS: Overexpression of leptin receptor predicts an unfavorable outcome in Middle Eastern ovarian cancer. Mol Cancer 8: 74, 2009.

48. Saxena NK, Sharma D, Ding X, Lin S, Marra F, Merlin D and Anania FA: Concomitant activation of the JAK/STAT,PI3K/AKT and ERK signaling is involved in leptin-mediated promotion of invasion and migration of hepatocellular carcinoma cells. Cancer Res 67: 2497-2507, 2007. 